ADALAH : Buletin Hukum \&

Keadilan

Buletin Hukum \& Keadilan

\title{
Mari Selamatkan Pancasila
}

\author{
A Salman Maggalatung ${ }^{\star}$
}

Pancasila dalam kedudukannya sebagai ideologi bangsa selalu menjadi perdebatan dan dan pertentangan. Hal ini berlangsung sejak awal kemerdekaan hingga masa sekarang. Pancasila seolah dijadikan sebagai sesuatu yang setara agama, sehingga siapapun yang menggunakannya dianggap menduakan agama yang diyakini warga negara. Tetapi memang pada masa orde baru, pengawalan terhadap Pancasila sangatlah berlebihan. Siapapun yang membenci Pancasila dianggap sebagai ancaman kedaulatan bangsa. Bahkan organisasi apapun yang tidak menjadikan ideologinya Pancasila dianggap sebagai organisasi pembangkang, separatis, dan anti -pancasila. Termasuk dalam hal ini seluruh komponen masyarakat diwajibkan menghayati dan mengamalkan Pancasila. Siswa SD, SMP, SMA dan Perguruan tinggi wajib melalui penataran P4. Tanpa melalui penataran P4, maka seseorang dianggap tidak memenuhi kualifikasi dapat memasuki lembaga tertentu.

Pancasila di Era Orde Baru memang dijadikan sebagai label demokrasi. Padahal sejatinya, tindakan mengawal Pancasila yang berlebihan tadi juga berakibat pada adanya ancaman terhadap Pancasila itu sendiri. Semua menyalahkan Pancasila,

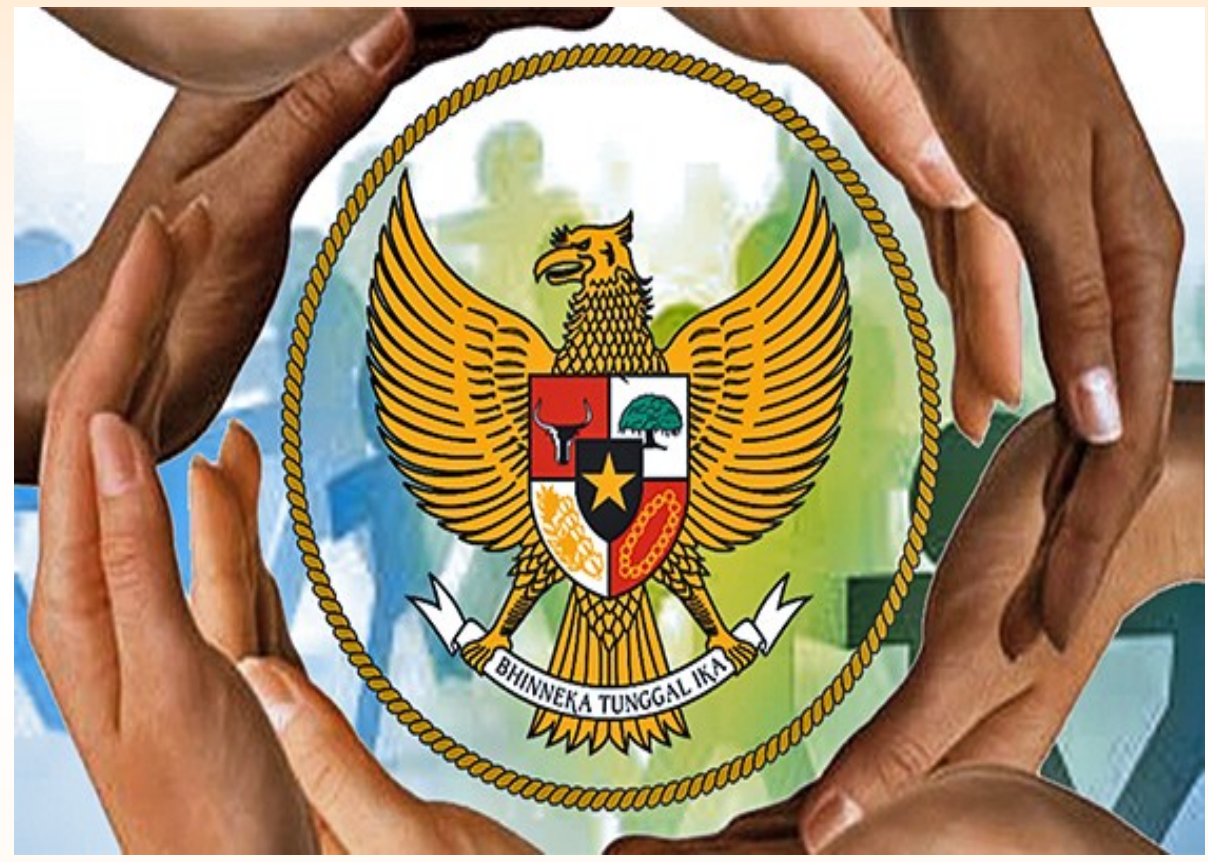

karena seolah menjadi momok yang menakut-nakuti masyarakat. Sehingga timbul suatu gerakan yang menolak Pancasila dijadikan sebagai ideologi dan asas tunggal. Karena pemaksaan terhadap Pancasila sebagai satu-satunya ideologi merupakan suatu perbuatan anti-demokrasi itu sendiri.

Pasca reformasi dan tergulingnya Orde Baru, Pancasila nyaris tenggelam. Banyak yang melupakan pancasila, kecuali Pancasila yang hanya dijadikan sebatas pajangan di dada Burung Garuda lambang negara. Pancasila tidak lagi dijadikan asas dan ideologi dari semua partai. Ironisnya di beberapa perguruan tinggi menghapuskan matakuliah pendidikan Pancasila, dan menggantinya dengan mata kuliah lain yang diinginkan kampus setempat. Pandangan masyarakat semacam ini tentu tidak dapat dilepaskan dari warisan masa silam, khususnya di era pemerintahan orde baru, Soeharto. Pada era itu, Pancasila diinternalisasikan langsung ke dalam masyarakat semacam doktrin kehidupan bangsa Indonesia dan karena itu pula masyarakat berinteraksi langsung. Selain diinternalisasikan, Pancasila juga dijadikan alat legitimasi rezim yang oleh banyak pihak dinilai otoritarian. Maka tidak mengherankan apabila kemudian mendapat penolakan keras sebagian masyarakat Indonesia 
yang tidak menyetujuinya, yang titik baliknya terjadi diawal era reformasi dimana Pancasila nyaris pada titik nadir, tenggelam bahkan ditenggelamkan.

Perbuatan melakukan penolakan terhadap Pancasila sama dengan penolakan terhadap dasar negara. Artinya, tanpa dasar negara, maka Indonesia menjadi tidak ada artinya (Riyanto, 2007: 467). Meninggalkan Pancasila sama saja dengan menenggelamkan cita-cita founding fathers mendirikan Negara Kesatuan Republik Indonesia dalam bingkai Bhineka Tunggal Ika. Padahal jelas dengan adanya Pancasila, maka perbedaan antar suku, ras, agama, dan tabiat dapat disatukan, karena kesamaan jiwa bangsa yang terkadung dalam sila-sila yang lima dari Pancasila. Oleh karena itu, Pancasila harus tetap menjadi Ideologi bersama, menyatukan bangsa Indonesia dalam perbedaan agama dan keyakinan.

Sebagai Philosofische grondslag, status ideologi tentu tidak dapat langsung diterapkan dalam kehidupan bermasyarakat, berbangsa dan bernegara, karena masih berupa ide atau nilai nilai dasar, masih berupa cita-cita bersama. Ideologi harus dikongkritkan menjadi sebuah konsep dasar berbangsa dan bernegara, kemudian konsep dasar bernegara dijabarkan menjadi sistem berbangsa dan bernegara. Jadi ide, tujuan dan dasar bernegara dijadikan sebagai ideologi yang tertuang dalam Pembukaan UUD 1945, sedang konsep dasar bernegara tertuang dalam batang tubuh UUD 1945, dan sistem berbangsa bernegara tertuang dalam peraturan perundangundangan. Apabila hal ini terwujud, maka masyarakat Indonesia tidak perlu berinteraksi langsung dengan ideologi. Tetapi langsung kepada peraturan perundangundangan. Akan tetapi, apakah semua peraturan peraturan perundang-undangan yang ada sudah sesuai dengan ideologi Pancasila. Dalam hal ini patut dikatakan bahwa Pancasila merupakan contoh ideologi campuran, karena merupakan perpaduan dari berbagai unsur ideologi murni yaitu liberalisme dan sosialisme ditambah dengan nilai-nilai moral dan budaya Indonesia (Yunus, 2015: 164).

Secara kontekstual akan terlihat bahwa dalam kehidupan bermasyarakat, berbangsa dan bernegara, masih banyak fenomena yang menjadi petunjuk adanya ketidaksesuaian antara ideologi, konsep dasar dan sistem berbangsa bernegara. Masih banyak ketidakharmonisan antara peraturan perundang- undangan dengan ideologi pancasila, bahkan dengan konsep dasar bernegara yaitu pasal-pasal dalam UUD NRI 1945. Sehingga kemudian menimbulkan kritik dan penolakan terhadap sistem ekonomi yang diimplementasikan, perilaku tindak kekerasan yang terkesan tidak tertangani dan terbiarkan, timbulnya radikalisme yang menghasilkan terorisme, ketidakjelasan dan ketidaktegasan perlindungan pemerintah terhadap warga yang bekerja sebagai TKI, terjadinya pelanggaran yang didasarkan atas nama SARA, selain juga kejahatan pelanggaran Hak Asasi Manusia.

Fenomena inilah yang kemudian patut dijadikan acuan dalam mengevaluasi negeri. Betapa pentingnya Pancasila dijadikan ideologi pemersatu bangsa. Sehingga Pancasila harus diselamatkan bukan

\footnotetext{
'Adalah; Buletin Hukum dan Keadilan merupakan berkala ilmiah yang diterbitkan oleh Pusat Studi Konstitusi dan Legislasi Nasional (POSKO-LEGNAS), Fakultas Syariah dan Hukum UIN Syarif Hidayatullah Jakarta.
}

Penasehat: Prof. Dr. H. Abdul Ghani Abdullah, SH., Prof. Dr. H. A Salman Maggalatung, SH., MH. Pemimpin Redaktur: Indra Rahmatullah, Tim Redaktur: Nur Rohim Yunus, Fathuddin, Mara Sutan Rambe, Muhammad Ishar Helmi, Erwin Hikmatiar. Penyunting: Indah Furba, Hasin Abdullah. Setting \& Layout: Siti Anisaul Kamilah.

ditenggelamkan. Meninggalkan Pancasila sama halnya dengan meninggalkan Indonesia yang sebenarnya. Sehingga tanpa disadari, Pancasila semakin jauh terlupakan, dan negara Indonesia seolah tanpa dasar pijakan. Oleh karenanya, mari Selamatkan Pancasila!

\section{Pustaka Acuan:}

* Guru Besar UIN Syarif Hidayatullah pada bidang Hukum Tata Negara, sekaligus Direktur Eksekutif Pusat Studi Konstitusi dan Legislasi Nasional UIN Jakarta.

Riyanto, Astim. Pancasila Dasar Negara Indonesia, Jurnal Hukum dan Pembangunan, Vol. 37 No. 3 JuliSeptember (2007)

Yunus, Nur Rohim. Aktualisasi Demokrasi Pancasila dalam Kehidupan Berbangsa dan Bernegara. SOSIO DIDAKTIKA: Social Science Education Journal, Volume 2 Nomor 2 (2015). doi:10.15408/sd.v2i2.2815. 